San Jose State University

SJSU ScholarWorks

$1-1-2013$

\title{
The role of elevation and soil chemistry in the distribution and ion accumulation of floral morphs of Streptanthus polygaloides Gray (Brassicaceae), a Californian nickel hyperaccumulator
}

\author{
N Pope \\ University of Texas at Austin \\ M Fong \\ San Jose State University \\ R Boyd \\ Auburn University Main Campus \\ N Rajakaruna \\ San Jose State University, nrajakaruna@gmail.com
}

Follow this and additional works at: https://scholarworks.sjsu.edu/biol_pub

Part of the Plant Biology Commons

\section{Recommended Citation}

N Pope, M Fong, R Boyd, and N Rajakaruna. "The role of elevation and soil chemistry in the distribution and ion accumulation of floral morphs of Streptanthus polygaloides Gray (Brassicaceae), a Californian nickel hyperaccumulator" Plant Ecology and Diversity (2013): 1-39. https://doi.org/10.1080/ 17550874.2013.783141

This Article is brought to you for free and open access by the Biological Sciences at SJSU ScholarWorks. It has been accepted for inclusion in Faculty Publications, Biological Sciences by an authorized administrator of SJSU ScholarWorks. For more information, please contact scholarworks@sjsu.edu. 


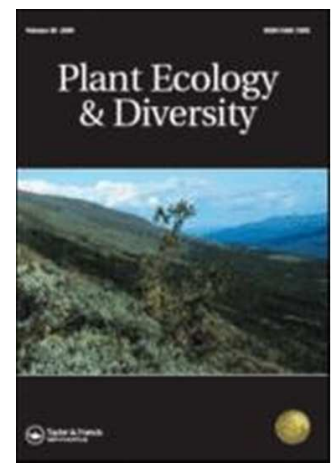

The role of elevation and soil chemistry in the distribution and ion accumulation of floral morphs of Streptanthus polygaloides Gray (Brassicaceae), a Californian nickel hyperaccumulator

\begin{tabular}{|r|l|}
\hline Journal: & Plant Ecology \& Diversity \\
\hline Manuscript ID: & TPED-2012-0068.R3 \\
\hline Manuscript Type: & Serpentine Conference Coimbra \\
\hline Keywords: & $\begin{array}{l}\text { floral divergence, local adaptation, plant endemism, serpentine ecology, } \\
\text { Streptanthus polygaloides }\end{array}$ \\
\hline
\end{tabular}

\section{SCHOLARONE ${ }^{m}$}

Manuscripts 
The role of elevation and soil chemistry in the distribution and ion accumulation of floral morphs of Streptanthus polygaloides Gray (Brassicaceae), a Californian nickel hyperaccumulator

\begin{abstract}
Background: The flora of serpentine / ultramafic soils provides an excellent model system for the study of natural selection in plant populations. Streptanthus polygaloides is a nickel hyperaccumulator that is endemic to serpentine soils in the Sierra Nevada of California, and has four floral morphs (yellow, purple, yellow-to-purple, and undulate).

Aims: We investigate three hypotheses: (1) the purple morph occurs in colder, wetter climates than the yellow morph; (2) tissue-soil ionic relationships differ among morphs; and (3) morphs occur on soils with differing elemental concentrations.
\end{abstract}

Methods: We queried herbarium records to investigate patterns of occurrence among the yellow and purple floral morphs, and analysed soil and tissue samples from wild populations of all four morphs.

Results: The purple morph inhabited serpentine outcrops with colder temperatures and greater precipitation levels than the yellow morph. Concentrations of elements in leaf tissue and rhizosphere soil differed little among populations of the morphs, but showed substantial within-site variation.

Conclusions: Our results suggest that a climatic gradient may be responsible for divergence in floral color among populations of $S$. polygaloides. Because of the large within-site variation in soil and tissue elemental concentrations, plants appear to have a varied physiological response to edaphic factors, regardless of morph membership.

Keywords: floral divergence, local adaptation, plant endemism, serpentine ecology, Streptanthus polygaloides 


\title{
Introduction
}

\begin{abstract}
When closely related taxa overlap in geographic range their distribution may be related to differential relationships of relevant environmental variables with plant fitness, i.e. through fine scale habitat specialisation (Dudley 1996; Sultan 2001; Yost et al. 2012). Habitat specialisation can have significant evolutionary consequences (Berenbaum 1996), even contributing to speciation (Kay et al. 2011). However, when habitats are small and isolated (i.e. patchy), small populations of habitat specialists (i.e. narrow endemics) could face increased risk of extinction (Schluter 2002; Ackerly 2003).
\end{abstract}

Edaphic islands such as serpentine outcrops are a 'model system' for studying the evolution and ecology of narrowly endemic taxa (Harrison and Rajakaruna 2011). The adverse soil chemical and physical conditions, and the discontinuous habitat distribution of serpentine outcrops, are conducive to the genetic differentiation of the resident flora, often resulting in high levels of local and regional endemism (Harrison et al. 2006). The literature provides numerous instances where the occurrence of species, subspecies, and races is linked to specific edaphic factors, including the differentiation of edaphic ecotypes and edaphically endemic species (Strid et al. 2003; O'Dell and Rajakaruna 2011).

Streptanthus polygaloides Gray (Brassicaceae), occurring on the western slopes of the Sierra Nevada of California, is a serpentine endemic (Baldwin et al. 2012). It is especially suited as a model organism for the study of natural selection at the population level because it is an annual plant with restricted habitat requirements that occurs along a steep elevation gradient. Individual populations may exhibit a greater degree of reproductive isolation than more widespread plant taxa. It is possible that scattered metapopulations of $S$. polygaloides represent ecologically distinct ecotypes. Classically, investigations of speciation have been retrospective comparisons of related taxa that have already 
diverged (Via 2009). However, documenting divergent evolution at the population level can provide insight into the ecological factors that drive the early stages of the evolution of reproductive isolation among ecologically divergent populations (Via 2009; Sobel et al. 2010).

Local adaptation in $S$. polygaloides may be accelerated by selective pressures resulting from biotic interactions, such as herbivory. Streptanthus polygaloides is a hyperaccumulator of nickel (Ni) (Reeves et al. 1981), and Martens and Boyd (1994) suggested that S. polygaloides evolved Ni hyperaccumulation as a defensive trait to protect against herbivores and disease. The Elemental Defence Hypothesis (Boyd 2010) has been tested extensively by using S. polygaloides (see Boyd 2009 for review) and, along with investigations of defence by other species that hyperaccumulate nickel (as well as species that hyperaccumulate other elements), provides one ecological explanation for the evolution of the hyperaccumulation trait (Strauss and Boyd 2011).

The taxonomic status of $S$. polygaloides is a matter of some debate. Greene (1904) suggested that S. polygaloides be transferred to a monospecific genus, Microsemia, on the basis of unique floral characteristics. Reeves et al. (1981) seconded this proposed division with the observation that $S$. polygaloides was the only Ni hyperaccumulator in the genus, whereas Mayer and Soltis (1994) retained S. polygaloides in Streptanthus on the basis of chloroplast DNA analysis.

Wall and Boyd (2006) documented four floral morphs of S. polygaloides that varied according to sepal color. The four morphs consisted of two with geographic distributions ranging from northern California (USA, $\sim 39$ degrees N.) to central California (USA, $~ 37.5$ degrees N), and two with restricted distributions. The more common of the widely distributed morphs had yellow (Y) sepals, and the less common had purple $(\mathrm{P})$ sepals. One range-restricted morph had pale yellow undulate (U) 
sepals, and the sepals of the other (YP morph) changed from yellow to purple during maturation of the inflorescence. In a common garden experiment using Ni-supplemented potting soil, Boyd et al. (2009) grew individuals from all four morphs and found substantial differences of foliar elemental concentrations (including Ni) and morphology among the four morphs. Boyd et al. (2009) reported that the recorded occurrences of the four morphs were allopatric with regards to each other and this, in combination with observed differences from the common garden experiment, suggested that the four morphotypes might be genetically distinct. If they were, then they might deserve taxonomic recognition and adequate conservation management, especially for the two morphs that have restricted distributions (YP and U). Boyd et al. (2009) observed that, of the populations from which they had collected seeds, the P morph grew at higher elevations (820-1100 m, 3 sites) than those of the other morphs (300-835 m, 7 sites across 3 morphs); thus, environmental factors other than edaphic may be responsible for floral differentiation among the morphs.

In this study we investigated distributional patterns of the two widespread morphs ( $\mathrm{Y}$ and $\mathrm{P}$ ) with regards to elevation and climate, along with tissue elemental composition and edaphic features of all morphs of $S$. polygaloides. We addressed the following hypotheses: (1) the Y and P morphs occur at separate edges of a climatic gradient in the western Sierra Nevada of California; (2) the morphs differ in their physiology, as expressed in mean foliar elemental concentrations and soil-tissue elemental relationships; (3) the morphs occur on soils with different edaphic regimes.

\section{Materials and methods}

Floral morph distribution and climate relationship 
Herbarium collection data, obtained from participants in the Consortium of California Herbaria (http://ucjeps.berkeley.edu/consortium/), were queried for geographic coordinates (Figure 1) and flower colour. A total of 99 specimens of the $\mathrm{Y}$ and $\mathrm{P}$ morphs comprised a dataset used to investigate elevational and climatic trends in the occurrence of the two morphs. These herbarium specimens represent collections made between 1880 and 2009. The bulk of collections ( 85 of 99) fell between 1950 and 2009, and only one was collected prior to 1900. All 99 collections were separated by at least $0.5 \mathrm{~km}$, and most by much more. Density-based clustering of collections indicates their spatial grain: 97 clusters with an inclusion distance of $2 \mathrm{~km}, 68$ clusters with an inclusion distance of $10 \mathrm{~km}$, and 10 clusters with an inclusion distance of $100 \mathrm{~km}$. Populations of YP and U morphs are rare and herbarium collections were too few to use in this analysis. The climate and elevation data used in association with these specimens were generated from the WorldClim global climatic data of Hijmans et al. (2005) and the National Elevation Dataset of the United States Geological Survey (Gesch 2007), respectively. We used nine bioclimatic variables from the WorldClim dataset: temperature (annual, maximum of warmest month, minimum of coldest month), precipitation (annual, maximum of wettest month, minimum of driest month), diurnal range, isothermality (diurnal range divided by temperature range), and temperature seasonality (the standard deviation of annual temperature). These climate data are interpolated to fine-scale resolutions from multiple sources, and represent averages from 1950 to 2000. Although some older herbarium specimens fell outside this temporal range, they added information about elevation. None of these older specimens were outliers relative to morph means for elevation (all but one Y collection fell within the $50 \%$ quantile).

Collection of live tissue and soil samples 
A second dataset was generated from elemental analysis of tissue and soil samples from eleven populations of $S$. polygaloides (Table 1; Figure 1, arrow marks). Of these eleven populations, two were of the U morph, two of the YP morph, three of the P morph, and four of the Y morph. In the spring of 2009, foliar samples were collected from the rosettes of four plants in each of these populations. Sampled plants were at the same phenological stage (just prior to anthesis). Samples consisted of seven to eight leaves; these were rinsed in the field with deionised water and stored in paper bags. In the lab, leaves were washed again with a $1 \mathrm{M} \mathrm{HCl}$ solution (one rinse) and deionised water (three rinses). At least $50 \mathrm{~g}$ of soil was collected from the rhizosphere of each sampled plant. Soil was collected with a plastic trowel from a depth of ca. $15 \mathrm{~cm}$ and stored in sealed plastic bags. Soil samples were then air-dried in the lab.

Analysis of tissue and soil samples

Rinsed tissues were air-dried for 3 days in paper towels before being dried at $110^{\circ} \mathrm{C}$ in a forced draft oven for $48 \mathrm{~h}$. Total tissue elemental concentrations for all elements (Al, B, Ca, $\mathrm{Cu}, \mathrm{Fe}, \mathrm{K}, \mathrm{Mg}$, $\mathrm{Mn}, \mathrm{Ni}, \mathrm{P}$, and $\mathrm{Zn}$ ) were determined by dry incineration at $450{ }^{\circ} \mathrm{C}$ for $5 \mathrm{~h}$, followed by digesting in $50 \%$ $\mathrm{HCl}$, and by using inductively coupled plasma optical emission spectrometry. Levels of $\mathrm{Cu}$ were generally below the detection limit and were not included in subsequent analyses.

Soil analyses were carried out on the $<2 \mathrm{~mm}$ fraction (obtained by using a brass sieve). Values for $\mathrm{pH}$ were obtained following Kalra and Maynard (1991), using the 1:2 soil to solution method with distilled water. Soils were analysed for $\mathrm{Al}, \mathrm{Cd}, \mathrm{Cr}, \mathrm{Cu}, \mathrm{Fe}, \mathrm{Mn}, \mathrm{Mo}, \mathrm{Ni}, \mathrm{Pb}$, and $\mathrm{Zn}$ by extraction with 0.005 $\mathrm{M}$ diethylene triamine pentaacetic acid (DTPA) buffered with triethanolamine to $\mathrm{pH} 7.3$ 
(Lindsay and Norvell 1978) for $2 \mathrm{~h}$ and subsequent detection by ICP-OES using matrix-matched calibration standards. Soils were analysed for exchangeable cations ( $\mathrm{Ca}, \mathrm{K}, \mathrm{Mg}$, and $\mathrm{Na}$ ) by extraction with $1 \mathrm{M}$ neutral ammonium acetate at $\mathrm{pH} 4.8$ (modified Morgan extract) and concentrations determined by ICP-OES analysis. Phosphorus was analysed colorimetrically by an ion analyser. Nitrogen $\left(\mathrm{NO}_{3}{ }^{-}\right.$and $\left.\mathrm{NH}_{4}{ }^{+}\right)$was determined by extraction in a $1 \mathrm{M} \mathrm{KCl}$ solution and measured colorimetrically by an ion analyzer (Burt 2004). Organic matter was measured by loss on ignition (LOI) at $375^{\circ} \mathrm{C}$. Elemental analyses were conducted by the Analytical Laboratory of the University of Maine at Orono (UMO).

\section{Statistical analysis}

All statistical analyses were implemented with the open-source statistical platform R (R Development Core Team 2012). Using the herbarium collection dataset, the frequencies of herbarium specimens of the $\mathrm{Y}(n=77)$ and $\mathrm{P}(n=22)$ morphs along an elevational and climatic gradient were examined with a generalised linear mixed model using the Laplace approximation (package Ime4; Bates et al. 2011). A random effect was added to account for geographic clustering in the data; cluster membership was determined using DBSCAN clustering based on $100 \mathrm{~km}$ exclusion distances (package fpc; Hennig 2010). The first two principal components of the nine variance-scaled climatic variables (listed above) and elevation were included as fixed effects.

Using the tissue and soil sample data for all four morphs (P, U, Y, and YP, $n=44$ plants in 11 sites), the relationships between tissue elemental concentrations, soil elemental concentrations, and morphotype were investigated by multiple linear mixed-effect models (package lme4), with site as a 
random effect. Soils were not analysed for B, therefore a single non-null model was fit for B. Models were fit by using maximum likelihood (ML) to facilitate model selection using AICc, and parameter estimates and predictions were averaged across models according to Akaike weights (package MuMIn; Barton 2012). Variables were log-transformed when necessary to normalise residuals and reduce the influence of outliers. Likelihood ratio tests between the best-fit models and the null model were used to generate $P$-values that were then corrected for false discovery rate (FDR) at $\alpha=0.05$, using the Benjamini-Hochberg method (Benjamini and Hochberg 1995). Correcting for FDR has been recommended over family-wise methods (i.e. Bonferroni) in analyses where multiple comparisons are between inter-correlated dependent variables, and the purpose is explanatory rather than confirmatory (Waite and Campbell 2006). Differences in soil and foliar elemental concentrations among morphs were estimated by using a post-hoc Tukey test for unbalanced data implemented in the package $\boldsymbol{\mu T \text { Toss }}$ (MuToss Coding Team 2012). The 'importance' of a variable is defined as the sum of Akaike weights (which are model-specific probabilities, conditional on the model set) for models containing that variable, and indicates the relative explanatory power of that variable (Burnham and Anderson 2002). Models were refit by using restricted estimated maximum likelihood (REML) to obtain estimates of variance components.

To quantify elemental variability in soils supporting morphs (referred to as soil-only data in text), we fitted multiple linear mixed effect models (package Ime4) with fixed morph and random site effects. Models were compared with AICc and likelihood ratio tests: variance components, corrections for FDR, and post-hoc tests were as for tissue variables above. Unless otherwise indicated, we defined statistical significance for slopes and mean differences as the $95 \%$ confidence interval not overlapping 
zero, and we defined 'substantial evidence' that a model is poorly supported relative to the best model in the context of multi-model comparison as $\Delta \mathrm{AICc} \geq 2$ (Burnham and Anderson 2002).

\section{Results \\ Morph distribution along an climatic gradient}

The first two principal components (PC1 and PC2; 64\% and 24\% of the variance among predictors, respectively) were used as fixed effects in the generalised mixed model. PC1 represented an environmental gradient associated with the Sierra Nevada: high values of PC1 indicate high temperatures, little precipitation, and low elevation. PC2 represented measures of temperature extremes: higher values indicate a greater range of temperatures within months, across the entire year (higher diurnal range and isothermality; Table 2). Temperature seasonality (expressed as the standard deviation of mean temperature) loaded onto PC1 rather than PC2, indicates that variability in monthly temperatures increases with increasing temperatures. The lack of correlation between temperature seasonality and PC2 was probably due to the relative frequencies of temperature extremes of equal magnitude: areas with frequent temperature extremes would have a high temperature range and a high standard deviation while areas with rare temperature extremes would have a high temperature range and a low standard deviation. Morph Y occurred more frequently and generally occupied hot and arid sites at lower elevations, while morph P occupied cooler, wetter sites at higher elevations (Figure 2). Temperature seasonality had little effect on frequencies of morphs (Tables 3 and 4). 


\section{Inter-morph variation in metal accumulation}

We considered five models to explain variation in mean levels of elements in foliar tissue (Table 5). The five biological hypotheses represented by these models were as follows (Table 6). 'Interactive' represented a separate response of foliar element vs. soil element for each morph (expressed as an interaction between morphotype and soil element). 'Additive' represented a monotonic response of an element in foliar tissue versus in soil across morphs; i.e. foliar elemental content was explained by a 'morph' effect (i.e. distinct mean values for each morph) plus a soil effect (i.e. greater levels of soil element equate to greater levels of foliar element). 'Soil' represented a correlation between levels of an element in soil and in tissue, without the morph-specific means. 'Morph' represented morph-specific means without a correlation between soil and foliar tissue. 'Null' represented a null hypothesis describing only random variation in a foliar element.

Model selection by AICc indicated that foliar tissue concentrations of $\mathrm{B}, \mathrm{Mg}$, and $\mathrm{Ni}$ varied little among morphs and were not correlated with corresponding soil elements. Although foliar Fe, P, and $\mathrm{Zn}$ were best explained by the null model of only random variation, AICc values for these elements provided some support for variation among morphs or correlations between soil and tissue concentrations - but not as additive effects in a single model (only 'Soil' and 'Morph' models had $\Delta$ $\mathrm{AICc} \leq 2)$. AICc values for foliar Al and $\mathrm{Zn}$ provided some support for the 'additive' model $(\Delta \mathrm{AICc} \leq$ 2), suggesting variation between morphs plus a correlation with the corresponding soil element, although the best model for foliar Al included only variation between morphs. Foliar Ca, K, and Mn were best explained by correlations with corresponding soil elements (Table 6). There was no evidence for an interaction between soil elements and morphs for any measured foliar element, indicating that morphs did not vary in the strength or direction of correlations between soil and tissue 
concentrations. Likelihood ratio tests agreed with AICc results in finding a significant morph effect for $\mathrm{Al}$ and a soil effect for $\mathrm{Ca}, \mathrm{K}$, and Mn after correcting for FDR (Table 7).

Morph U had significantly $(\alpha=0.05)$ more foliar Al than the other morphs, and morph YP had significantly less foliar P than morph Y. Concentrations of Ca and $\mathrm{K}$ showed a significant positive correlation, and Mn a significant negative correlation, between soil and tissue (Table 7). Within-site variance substantially exceeded between-site variance for most elements (Table 6, Supplementary Figure S1). The inclusion of highly explanatory (significant) fixed effects decreased between-site variance rather than within-site variance.

\section{Variation among soils supporting morphs}

Model comparison with AICc indicated variation among morphs for soil Fe and K (Table 8). Although AICc scores indicated variation among morphs for soil $\mathrm{Ca}, \mathrm{Mo}, \mathrm{Na}$, and $\mathrm{pH}$, the null hypothesis of only random variation between morphs also had some support ( $\triangle \mathrm{AICc} \leq 2)$. Although the null hypothesis was preferred for soil $\mathrm{Cd}$, the hypothesis of variation between morphs also had some support. Likelihood ratio tests agreed with AICc results in finding a significant morph effect for soil Fe and $\mathrm{K}$ after correction for FDR. The soil of morph $\mathrm{P}$ had significantly less Na than did soil of morphs $\mathrm{U}$ and $\mathrm{Y}$. The soil of morph $\mathrm{U}$ had significantly greater $\mathrm{K}$ than did the soil of the other morphs, and greater Mo and $\mathrm{pH}$ and less Fe than the soil of morphs Y and P. The soil of morph YP had significantly greater $\mathrm{Ca}$ than soil of morphs $\mathrm{Y}$ and $\mathrm{P}$, and less Fe than soil of morph $\mathrm{P}$. Estimated within-site variances were less than or equivalent to between-site variances for all soil variables except $\mathrm{Ca}, \mathrm{Cr}, \mathrm{Fe}, \mathrm{Pb}$, and $\mathrm{Zn}$, indicating substantial variability in soils among sites. 


\section{Discussion \\ Climate influences morph occurrence}

In support of our first hypothesis (that $\mathrm{Y}$ and $\mathrm{P}$ morphs occur at separate edges of a climatic gradient in the western Sierra Nevada of California), we found that herbarium collections of the $\mathrm{P}$ morph occurred at colder temperatures and higher levels of precipitation, than did the more widespread Y morph. The mechanism responsible for the difference in floral colour is unknown, although selection for anthocyanin expression in plant floral tissue and foliage has been linked with resistance to stress caused by abiotic (i.e., high temperatures and drought) and biotic (i.e., herbivory) factors (Whittall and Strauss 2006). In Collinsia sparsiflora (Scrophulariaceae), some purple-flowered populations are locally adapted to serpentine soils (Wright and Stanton 2011), with those on serpentine showing significant allele frequency differences at one locus, malic enzyme (Me). Such allele frequency differences are a starting point for further genetic analysis aimed at identifying genes responsible for adaptive differentiation, including the significance of flower colour to substrate tolerance (von Wettberg and Wright 2011). Similarly, in both Leptosiphon androsaceus and L. parviflorus (Polemoniaceae), purple flowered populations are locally adapted to serpentine soils (Kay et al. 2011; O’Dell and Rajakaruna 2011). Interestingly, the purple flowered serpentine populations of Collinsia sparsiflora (Wright and Stanton 2011) and Leptosiphon parviflorus (Kay et al. 2011) always flower early, suggesting that drought avoidance may be an important adaptation, indirectly contributing to reproductive isolation, even when populations of different morphs are found in the same geographic region (Rajakaruna 2004). A review of literature on plants with purple - white colour polymorphisms 
has shown that in several taxa, across many plant families, purple-flowered individuals were more drought and heat tolerant than those with white flowers (Whittall and Strauss 2006), although it is unclear if there is a direct causal relationship between anthocyanin and tolerance to water/heat stress (Rausher 2008). In contrast to this literature, we found the opposite colour pattern with reference to heat or drought stress. Although we found climate to be a statistically significant predictor of the presence of the $\mathrm{Y}$ versus $\mathrm{P}$ morphs, statistical significance only indicates a high probability of a nonzero regression coefficient. A non-random association between climate and morph occurrence may not reflect a direct or indirect causal link between climate factors and flower colour. Ecological pressures such as herbivory (Irwin et al. 2003, Whittall and Strauss 2006) and assortative mating due to different pollinators, can be linked to flower colour and may or may not vary within the range of climates within which the $\mathrm{Y}$ and $\mathrm{P}$ morphs occur.

\section{Among morph variation in soil-tissue ionic relationships}

With reference to our second hypothesis, that morphs differ in their physiology (as expressed in mean foliar elemental concentrations and soil-tissue elemental relationships), we found few differences in foliar element concentrations in wild collected plants, and none that were also observed among greenhouse-grown individuals of the four Streptanthus morphs. Boyd et al. (2009) reported significant differences in foliar macronutrients $(\mathrm{Ca}, \mathrm{K}$, and $\mathrm{P})$, and heavy metals $(\mathrm{Cu}, \mathrm{Mg}, \mathrm{Mn}, \mathrm{Ni}$, and $\mathrm{Zn})$ among the four morphs, with all four morphs separating out clearly in ordination. Following these results, we expected to find variation in these elements in wild populations, indicating local adaptation to edaphic factors in the four morphs. In contrast, we found substantial support ( $\Delta \mathrm{AICc} \leq 2)$ for a morph effect in 
foliar Al, Fe, Zn, and P. Differences in site soil characteristics may explain some variation between morphs - for example, foliar K was found in greater concentrations in the U morph than the other three morphs, but was attributable to higher levels of soil $\mathrm{K}$ - however, foliar concentrations of many elements did not correlate strongly with respective soil concentrations; only $\mathrm{Ca}, \mathrm{K}$, and $\mathrm{Mn}$ showed significant correlation (Table 7). Although selection for tolerance to edaphic factors can be strong (e.g. Ostevik et al. 2012), traits associated with these factors can be difficult to detect. The interactions mediating ion uptake in plants are complex and depend upon plant phenology, soil chemical and physical characteristics, biotic factors, and competition between ions. Uptake rates for plant nutrients vary at different soil concentrations of these nutrients, and are highly non-linear (Epstein and Bloom 2005). Thus, it is unsurprising that most of the elements analysed in this study showed no correlation between soil and tissue.

In contrast to our results, the findings of Boyd et al. (2009) strongly support the hypothesis that physiological differences exist among morphs. Greenhouse-grown plants are exposed to far fewer confounding factors than those collected from the wild, and it is likely that the effect of site and microhabitat in our study overwhelmed the effect of morph on observed foliar elemental concentrations. Additionally, the microsite effect may have more impact than the site effect: within-site variation equalled or exceeded between-site variation for foliar elements (Table 6), while the opposite pattern was observed for the majority of soil elements (Table 8). Kruckeberg and Reeves (1995) attributed differences in tissue Ni between field- and laboratory-grown S. polygaloides to phenological differences in greenhouse and natural populations. While the phenological state at collection time certainly contributes to observed differences in foliar elemental concentrations, we believe that phenology alone cannot explain the wide discrepancy between greenhouse and field results. 


\section{Among morph variation in soil chemistry}

Contrary to our hypothesis that morphs occur on soils with different edaphic regimes, we found few substantial differences among the soils supporting the various morphs. As expected, the most distinct soils were those supporting the geographically disjunct U morph. However, mean levels of only three soil elements differed substantially among the other three morphs (Table 8). In contrast, between-site variation was greater than within-site variation for most soil elements. These results indicate that floral morph in S. polygaloides is not linked to specific edaphic factors.

Although Boyd et al. (2009) provide convincing evidence that morphs differ in soil-tissue ionic relationships, the degree to which edaphic factors and climate variables interact in the realised distribution of the floral morphs deserves further investigation. The difficulty of extrapolating results from the common garden to natural populations is highlighted in our study, which finds little evidence of edaphic specialisation among morphs. We propose that a reciprocal field transplant study, commonly used to test for local adaptation (Wright and Stanton 2011; Yost et al. 2012), be used to test for local adaptation in S. polygaloides. For these experiments, it is important to better characterise soil surface temperature as well as relative water content in the rhizosphere of plants throughout the growing season. These data will allow a better assessment of the relationship of heat and drought to the fitness of the morphotypes. A greenhouse study should subsequently be conducted to determine if the morphs show differential fitness when exposed to a range of water and temperature treatments that simulate field conditions. Additionally, a population genetic study conducted on the four morphotypes found across the range of the species could provide insight to the within and among morphotype 
variation in S. polygaloides. The degree to which populations of morphs interbreed in nature is unknown; a population genetic study will help characterize the degree to which the morphs are reproductively isolated.

In all populations visited for this and prior studies by the authors (viz. removed for anonymity), the four floral morphs of $S$. polygaloides were allopatric, i.e. local populations always consisted of one morph. However, herbarium records place occurrences of YP in the areas north of Oroville and Merced, close to populations of other morphs (between 0.5 and $1 \mathrm{~km}$ ). Occurrences of the $\mathrm{Y}$ and $\mathrm{P}$ morphs were always separated by a minimum of several $\mathrm{km}$ : the smallest distance between the two morphs recorded by this study was $3 \mathrm{~km}$, and the mean was far greater at $116 \pm 15 \mathrm{~km}$ (median $77 \mathrm{~km})$. Thus populations of different morphs, especially of YP, may be parapatric in some cases.

Geographical reproductive isolation seems probable especially for the $\mathrm{U}$ morph, which is known from only a single disjunct serpentine area (Figure 1), but not for the other three morphs, which can occur relatively close to each other (see above) and sometimes on the same serpentine 'islands,' although to our knowledge never in mixed stands. Temporal reproductive isolation is possible for all morphs, and causal connections between edaphic variation and phenology are well documented for a number of plant species (for review see Levin 2009). Boyd et al. (2009) found that the YP and U morphs flowered later than the $\mathrm{Y}$ and $\mathrm{P}$ morphs when grown from seed under the same environmental conditions in a greenhouse. Ecological reproductive isolation, as a result of different cohorts of pollinators servicing different floral morphs, is possible given that the morphs are characterised by different floral colours and flower at different times. Future work is planned to elucidate the genetic relationships and hybrid status of the various morphs, including how microsite ecology may contribute 
to fitness trade-offs among the four morphs. The studies we plan to conduct are essential to better characterise factors contributing to the distribution pattern along the climatic gradient and determine what conservation measures are necessary to preserve genetic diversity among wild populations of the serpentine endemic and nickel-hyperaccumulating S. polygaloides.

Documenting the morphological, physiological, ecological, and genetic variation in edaphic endemics in montane areas (such as $S$. polygaloides) is a task of critical importance, as their natural habitat is continually lost to anthropogenic disturbance and climate change (Boyd et al. 2009; Damschen et al. 2011). Population-level data not only provide insight into evolutionary processes, but emphasise the importance of conserving novel, locally adapted ecotypes. In response to the imminent and accelerating environmental changes affecting Mediterranean ecosystems (Keeley et al. 2006; Safford and Mallek 2011), it is essential to conduct detailed studies on the biology and ecology of endemic, narrowly distributed taxa so informed decisions can be made with respect to their persistence, including management under climate change (Parmesan 2006). By informing federal and statewide conservation initiatives, these data provide the basis for enhanced conservation measures such as ex situ and in vitro preservation of germplasm (Li and Pritchard 2009), habitat preservation (Thorne et al. 2011), ecological restoration and assisted dispersal (McLachlan et al. 2007).

\section{Conclusions}

Our results suggest that the two widespread floral morphs of Streptanthus polygaloides occur at separate levels of a climatic gradient. Floral differentiation along this gradient could be due to exogenous ecological factors, or physiological differences. We found little evidence that morphs 
differed in concentrations of elements in foliar tissue or rhizosphere soil. These results contrast with the conclusions of a previous common garden study (Boyd et al. 2009), which found systematic variation in soil-tissue ion relationships among morphs. We suggest that this discrepancy in tissue chemistry could result from the wide within- and between-site variation in soil chemistry observed in wild populations of S. polygaloides. Future work is necessary to understand the extent of interbreeding and niche differentiation among morphs.

\section{References}

Ackerly DD. 2003. Community assembly, niche conservatism, and adaptive evolution in changing environments. International Journal of Plant Sciences 164: 165-184.

Baldwin BG, Goldman DH, Keil DJ, Patterson R, Rosatti TJ, Wilken DH, editors. 2012. The Jepson manual: Vascular plants of California. 2nd ed. Berkeley and Los Angeles (CA): University of California Press.

Barton K. 2012. MuMIn: Multi-model inference. R package version 1.7.0. http://CRAN.Rproject.org/package $=$ MuMIn

Bates D, Maechler M, Bolker B. 2011. lme4: linear mixed effects models using S4 classes. R package version 0.999375-42. http://CRAN.R-project.org/package=lme4

Benjamini Y, Hochberg Y. 1995. The control of the false discovery rate under dependency. Annals of Statistics 29: 1165-1188. 
Berenbaum MR. 1996. Introduction to the symposium: on the evolution of specialization. American Naturalist 148: 78-83.

Boyd RS. 2009. High-nickel insects and nickel hyperaccumulator plants: A review. Insect Science 16: 19-31.

Boyd RS. 2010. Heavy metal pollutants and chemical ecology: exploring new frontiers. Journal of Chemical Ecology 36: 46-58.

Boyd RS, Wall MA, Santos SR, Davis MA. 2009. Variation of morphology and elemental concentrations in the California nickel hyperaccumulator Streptanthus polygaloides (Brassicaceae). Northeastern Naturalist 16: 21-38.

Burnham KP, Anderson DR. 2002. Model selection and multi-model inference: a practical information-theoretic approach. 2nd ed. New York (NY): Springer-Verlag.

Burt R. 2004. Soil survey laboratory methods manual. Version 4.0. Washington DC: US Government Printing Office. Soil Survey Investigations Report 42. Available from: http://soils.usda.gov/technical/lmm/

Damschen EI, Harrison S, Going BM, Anacker BL. 2011. Climate change and special soil communities. In: Harrison S, Rajakaruna N, editors. Serpentine: The evolution and ecology of a model system. Berkeley and Los Angeles (CA): University of California Press. p. 359-381.

Dudley SA. 1996. The response to differing selection on plant physiological traits: evidence for local adaptation. Evolution 50: 103-110. 
Epstein E, Bloom AJ. 2005. Mineral nutrition of plants: principles and perspectives. 2nd ed. Sunderland (MA): Sinauer.

Gesch, DB. 2007. The national elevation dataset. In: Maune D, editor. Digital elevation model technologies and applications: the DEM users manual. Bestheda (MD): American Society for Photogrammetry and Remote Sensing. p. 99-118.

Greene EL. 1904. Certain west American Cruciferae. Leaflets of Botanical Observation and Criticism 1: $81-90$.

Harrison S, Safford HD, Grace JB, Viers JH, Davies KF. 2006. Regional and local species richness in an insular environment: serpentine plants in California. Ecological Monographs 76: 41-56.

Harrison S, Rajakaruna N, editors. 2011. Serpentine: the evolution and ecology of a model system. 1st ed. Berkeley and Los Angeles (CA): University of California Press.

Hennig C. 2010. fpc: Flexible procedures for clustering. R package version 2.0-3. Available from: http://CRAN.R-project.org/package $=\mathrm{fpc}$

Hijmans RJ, Cameron SE, Parra JL, Jones PG, Jarvis A. 2005. Very high resolution interpolated climate surfaces for global land areas. International Journal of Climatology 25: 1965-1978.

Irwin RE, Strauss SY, Storz S, Emerson A, Guibert G. 2003. The role of herbivores in the maintenance of a flower color polymorphism in wild radish. Ecology 84: 1733-1743.

Kalra YP, Maynard DG. 1991. Methods manual for forest soil and plant analysis. 1st ed. Edmonton (AB): Forestry Canada. Northwest region. Report no. NOR-X-319. 
Kay KM, Ward KL, Watt LR, Schemske DW. 2011. Plant Speciation. In: Harrison S, Rajakaruna N, editors. Serpentine: the evolution and ecology of a model system. Berkeley and Los Angeles (CA): University of California Press. p. 71-96.

Keeley JE, Allen CD, Betancourt J, Chong GW, Fotheringham CJ, Safford HD. 2006. A 21st century perspective on postfire seeding. Journal of Forestry 104: 1-2.

Kruckeberg AR, Reeves RD. 1995. Nickel accumulation by serpentine species of Streptanthus (Brassicaceae): field and greenhouse studies. Madroño 42: 458-469.

Levin DA. 2009. Flowering-time plasticity facilitates niche shifts in adjacent populations. New Phytologist 183: 661-666.

Li DZ, Pritchard HW. 2009. The science and economics of ex situ plant conservation. Trends in Plant Science 14: 614-621.

Lindsay WL, Norvell WA. 1978. Development of a DTPA soil test for zinc, iron, manganese, and copper. Journal of the Soil Science Society of America 42: 421-428.

Martens SN, Boyd RS. 1994. The ecological significance of nickel hyperaccumulation: a plant chemical defense. Oecologia 98: 379-384.

Mayer MS, Soltis PS. 1994. The evolution of serpentine endemics: a chloroplast DNA phylogeny of the Streptanthus glandulosus complex (Cruciferae). Systematic Botany 19: 557-574.

McLachlan J, Hellman J, Schwartz MW. 2007. A framework of debate of assisted migration in an era of climate change. Conservation Biology 21: 297-302. 
MuToss Coding Team. 2012. $\mu$ Toss: Unified multiple testing procedures. R package version 0.1-7. $\underline{\text { http://CRAN.R-project.org/package }=\text { mutoss }}$

O'Dell RE, Rajakaruna N. 2011. Intraspecific variation, adaptation, and evolution. In: Harrison S, Rajakaruna N, editors. Serpentine: the evolution and ecology of a model system. Berkeley and Los Angeles (CA): University of California Press. p. 97-137.

Ostevik KL, Moyers BT, Owens GL, Rieseberg LH. 2012. Parallel ecological speciation in plants? International Journal of Ecology 2012: 1-17.

Parmesan C. 2006. Ecological and evolutionary responses to recent climate change. Annual Review of Ecology, Evolution, and Systematics 37: 637-669.

R Development Core Team. 2012. R: a language and environment for statistical computing. Vienna, Austria: R Foundation for Statistical Computing. Available from: http://www.R-project.org

Rajakaruna N. 2004. The edaphic factor in the origin of plant species. International Geology Review 46: 471-478.

Rausher MD. 2008. Evolutionary transitions in floral color. International Journal of Plant Sciences 169: 7-21.

Reeves RD, Brooks RR, Macfarlane RM. 1981. Nickel uptake by Californian Streptanthus and Caulanthus with particular reference to the hyperaccumulator S. polygaloides Gray (Brassicaceae). American Journal of Botany 68: 708-712. 
Safford HD, Mallek CR. 2011. Disturbance and diversity in low-productivity ecosystems. In: Harrison S, Rajakaruna N, editors. Serpentine: the evolution and ecology of a model system. Berkeley and Los Angeles (CA): University of California Press. p. 249-274.

Schluter D. 2002. The ecology of adaptive radiation. Oxford (UK): Oxford University Press.

Sobel JM, Chen GF, Watt LR, Schemske DW. 2010. The biology of speciation. Evolution 64: 295-315.

Strauss SY, Boyd RS. 2011. Herbivory and other cross-kingdom interactions on harsh soils. In:

Harrison S, Rajakaruna N, editors. Serpentine: the evolution and ecology of a model system. Berkeley and Los Angeles (CA): University of California Press. p. 181-199.

Strid A, Andonoski A, Andonovski V. 2003. The high mountain vegetation of the Balkan Peninsula. In: Nagy L, Grabherr G, Koerner C, Thompson DBA, editors. Alpine biodiversity in Europe. Heidelberg, Berlin, and New York: Springer. p. 113-132.

Sultan SE. 2001. Phenotypic plasticity for fitness components in Polygonum species of contrasting ecological breadth. Ecology 82: 328-343.

Thorne JH, Huber PR, Harrison S. 2011. Systematic conservation planning: Protecting rarity, representation, and connectivity in regional landscapes. In: Harrison S, Rajakaruna N, editors. Serpentine: the evolution and ecology of a model system. Berkeley and Los Angeles (CA): University of California Press. p. 309-328.

Via S. 2009. Natural selection in action during speciation. Proceedings of the National Academy of Sciences 106: 9939-9946. 
von Wettberg EJ, Wright JW. 2011. Genomic approaches to understanding adaptation. In: Harrison S, Rajakaruna N, editors. Serpentine: the evolution and ecology of a model system. Berkeley and Los Angeles (CA): University of California Press. p. 139-154.

Waite TA, Campbell LG. 2006. Controlling the false discovery rate and increasing statistical power in ecological studies. Ecoscience 13: 439-442.

Wall MA, Boyd RS. 2006. Melanotrichus boydi (Heteroptera: Miridae) is a specialist on the nickel hyperaccumulator Streptanthus polygaloides (Brassicaceae). Southwestern Naturalist 51: 481489.

Whittall JB, Strauss SY. 2006. Non-pollinator agents of selection on floral traits. In: Harder L, Barrett S, editors. Ecology and evolution of flowers. Oxford University Press. p. 120-138.

Wright JW, Stanton ML. 2011. Local adaptation in heterogeneous landscapes. In: Harrison S, Rajakaruna N, editors. Serpentine: the evolution and ecology of a model system. Berkeley and Los Angeles (CA): University of California Press. p. 155-179.

Yost JM, Barry T, Kay KM, Rajakaruna N. 2012. Edaphic adaptation maintains the coexistence of two cryptic species on serpentine soil. American Journal of Botany 99: 890-897. 
Table 1. Geographic coordinates and elevation for 11 populations of Streptanthus polygaloides from which soil and leaf tissue samples were collected. -

\begin{tabular}{|c|c|c|c|c|}
\hline Morph & Population & Latitude & Longitude & Elevation (m) \\
\hline \multirow[t]{3}{*}{ Purple (P) } & Goodyear's Bar & N $39^{\circ} 32^{\prime} 33.58^{\prime \prime}$ - & W $120^{\circ} 53^{\prime} 4.20^{\prime \prime}$ - & 845 \\
\hline & Sugar Pine & N $39^{\circ} 7^{\prime} 24.24^{\prime \prime}$ - & W $120^{\circ} 46^{\prime} 57.36^{\prime \prime}$ - & 1084 \\
\hline & Washington Rd. & N 39² $20^{\prime} 7.69^{\prime \prime}$ - & W $120^{\circ} 48^{\prime} 8.28^{\prime \prime}$ - & 1180 \\
\hline \multirow[t]{4}{*}{ Yellow (Y) } & Bagby Rd. & N $37^{\circ} 36^{\prime} 47.27^{\prime \prime}-$ & W $120^{\circ} 8^{\prime} 25.44^{\prime \prime}$ - & 258 \\
\hline & Grass Valley & N $39^{\circ} 13^{\prime} 27.80^{\prime \prime}$ - & 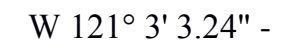 & 788 \\
\hline & Marshall Rd. & N $38^{\circ} 50^{\prime} 30.41^{\prime \prime}$ - & W $120^{\circ} 52^{\prime} 40.44^{\prime \prime}$ - & 546 \\
\hline & Red Hills & N $37^{\circ} 51^{\prime} 20.05^{\prime \prime}$ - & W $120^{\circ} 27^{\prime} 16.20^{\prime \prime}$ - & 323 \\
\hline \multirow[t]{2}{*}{ Yellow-purple (YP) } & County Line & N $37^{\circ} 46^{\prime} 20.32^{\prime \prime}$ - & W $120^{\circ} 15^{\prime} 34.92^{\prime \prime}$ - & 500 \\
\hline & San Andreas & N $38^{\circ} 13^{\prime} 16.64^{\prime \prime}$ - & W $120^{\circ} 42^{\prime} 2.88^{\prime \prime}$ - & 269 \\
\hline \multirow[t]{2}{*}{ Undulate (U) } & Trimmer & N 36 54' 1.94" - & W $119^{\circ} 16^{\prime} 42.60^{\prime \prime}$ - & 297 \\
\hline & Watts Valley & N $36^{\circ} 53^{\prime} 48.19^{\prime \prime}$ - & W $119^{\circ} 26^{\prime} 55.68^{\prime \prime}$ - & 356 \\
\hline
\end{tabular}


Table 2. Mean values \pm standard errors of environmental variables for herbarium collections of the four morphs of Streptanthus polygaloides, and principal component scores for these variables. 'Annual' refers to the mean annual value. Min, minimum temperature of coldest month; Max, maximum temperature of warmest month; Iso, isothermality (the 'evenness' of diurnal range across the year, i.e. the mean diurnal range divided by annual temperature range, multiplied by one hundred); DiR, diurnal range (mean range of monthly temperatures); TSd, temperature seasonality (standard deviation of annual temperature); Ele, elevation above sea level in meters; Range, latitudinal range (decimal degrees latitude); \%, percent of total variance explained by principal components. Letters refer to floral morphs: P, purple sepals; U, undulate sepals; Y, yellow sepals; YP, yellow to purple sepals.

\begin{tabular}{|c|c|c|c|c|c|c|c|c|c|c|c|c|}
\hline \multirow[b]{2}{*}{ Morph } & \multirow[b]{2}{*}{$n$} & \multicolumn{3}{|c|}{ Temperature $\left({ }^{\circ} \mathrm{C}\right)$} & \multicolumn{3}{|c|}{ Precipitation (mm) } & \multicolumn{3}{|c|}{ Seasonality } & \multirow[b]{2}{*}{ Ele.* } & \multirow[b]{2}{*}{ Range* } \\
\hline & & Annual & Min.* & Max.* & Annual & Wettest & Driest & Iso.* & DiR.* & TSd.* & & \\
\hline $\mathrm{P}$ & 22 & $\begin{array}{c}11.4 \\
\pm 0.4\end{array}$ & $\begin{array}{l}-1.5 \\
\pm 0.3\end{array}$ & $\begin{array}{l}30.0 \\
\pm 0.5\end{array}$ & $\begin{array}{l}1463 \\
\pm 66\end{array}$ & $\begin{array}{l}268 \\
\pm 12\end{array}$ & $\begin{array}{c}5 \\
\pm 0.3\end{array}$ & $\begin{array}{l}45.6 \\
\pm 0.3\end{array}$ & $\begin{array}{c}14.5 \\
\pm 0.25\end{array}$ & $\begin{array}{c}6.2 \\
\pm 0.3\end{array}$ & $\begin{array}{l}1140.5 \\
\pm 75.2\end{array}$ & $\begin{array}{c}37.73- \\
39.67\end{array}$ \\
\hline $\mathrm{U}$ & 2 & $\begin{array}{c}16.3 \\
\pm 0\end{array}$ & $\begin{array}{l}2.2 \\
\pm 0\end{array}$ & $\begin{array}{l}35.3 \\
\pm 0.2\end{array}$ & $\begin{array}{l}592 \\
\pm 34\end{array}$ & $\begin{array}{l}113 \\
\pm 7\end{array}$ & $\begin{array}{c}1 \\
\pm 0\end{array}$ & $\begin{array}{l}42.5 \\
\pm 0.5\end{array}$ & $\begin{array}{c}14.2 \\
\pm 0.25\end{array}$ & $\begin{array}{c}6.8 \\
\pm 0.2\end{array}$ & $\begin{array}{l}414.5 \\
\pm 43.5\end{array}$ & $\begin{array}{c}36.9- \\
36.9\end{array}$ \\
\hline $\mathrm{Y}$ & 77 & $\begin{array}{c}14.2 \\
\pm 0.2\end{array}$ & $\begin{array}{c}0.6 \\
\pm 0.1\end{array}$ & $\begin{array}{l}33.3 \\
\pm 0.2\end{array}$ & $\begin{array}{l}1089 \\
\pm 39\end{array}$ & $\begin{array}{l}209 \\
\pm 8\end{array}$ & $\begin{array}{c}2 \\
\pm 0.1\end{array}$ & $\begin{array}{l}44.6 \\
\pm 0.2\end{array}$ & $\begin{array}{l}14.7 \\
\pm 0.1\end{array}$ & $\begin{array}{c}6.3 \\
\pm 0.2\end{array}$ & $\begin{array}{l}585.8 \\
\pm 29.6\end{array}$ & $\begin{array}{c}37.48- \\
39.95\end{array}$ \\
\hline YP & 7 & $\begin{array}{c}13.5 \\
\pm 0.6\end{array}$ & $\begin{array}{l}-0.3 \\
\pm 0.6\end{array}$ & $\begin{array}{c}33.3 \\
\pm 0.6\end{array}$ & $\begin{array}{l}889.2 \\
\pm 75.1\end{array}$ & $\begin{array}{c}168.3 \\
\pm 14.8\end{array}$ & $\begin{array}{c}2.1 \\
\pm 0.4\end{array}$ & $\begin{array}{r}45.8 \\
\pm 0.2\end{array}$ & $\begin{array}{c}15.5 \\
\pm 0.2\end{array}$ & $\begin{array}{c}6.4 \\
\pm 0.6\end{array}$ & $\begin{array}{c}687.4 \\
\pm 95.6\end{array}$ & $\begin{array}{c}37.76- \\
40.07\end{array}$ \\
\hline \multicolumn{5}{|c|}{ Principal Component (PC) Loadings } & & & & & & & & $\%$ Var* \\
\hline $\mathrm{PC} 1$ & & 0.36 & 0.31 & 0.38 & -0.33 & -0.32 & -0.33 & -0.02 & 0.19 & 0.34 & -0.36 & $64 \%-$ \\
\hline $\mathrm{PC} 2$ & & -0.20 & -0.35 & -0.02 & -0.23 & -0.26 & -0.07 & 0.60 & 0.54 & -0.07 & 0.16 & $19 \%-$ \\
\hline
\end{tabular}


Table 3. Model selection using AICc for environmental factors related to floral morph (yellow and purple morphs) in herbarium collection data from central California, USA ( $n=99$; collections from approximately 37 to 40 degrees N, 120 to 122 degrees $\mathrm{W}$ ). $\sigma$, variance associated with the random cluster effect; Dev., residual deviance tested by the likelihood ratio tests; $k$, number of parameters in the model; weight, relative Akaike weight given the model. $P$ values were derived from likelihood ratio tests of nested models; a significant value indicates that the complex model was preferred. Bold font indicates the minimum adequate model.

\begin{tabular}{lcccccc}
\hline \multicolumn{1}{c}{ Model for floral morph (FM) } & $\boldsymbol{\sigma}$ & Dev. & $\boldsymbol{K}$ & AICc & Weight & $\boldsymbol{P}$ \\
\hline FM $\sim$ elevation/climate effects, seasonality effects & 3.85 & 43.1 & 4 & 51.5 & 0.265 & $\cdot$ \\
FM $\sim$ elevation/climate effects & $\mathbf{3 . 8 5}$ & $\mathbf{4 3 . 2 3}$ & $\mathbf{3}$ & $\mathbf{4 9 . 5}$ & $\mathbf{0 . 7 3 5}$ & $\mathbf{0 . 7 1}$ \\
FM $\sim$ seasonality effects & 2.39 & 59.44 & 3 & 65.7 & 0.000 & $<0.001$ \\
FM $\sim$ intercept only (NULL) & 2.45 & 59.61 & 2 & 63.7 & 0.001 & $<0.001$ \\
\hline
\end{tabular}


Table 4. Model-averaged parameter estimates from the floral morph (yellow and purple morphs) models for the herbarium collection data from central California, USA ( $n=99$; collections from approximately 37 to 40 degrees N, 120 to 122 degrees W). SE is unconditional standard error, 95\% CI is the conditional confidence interval and importance is the importance of the variable based on Akaike weights. $P$ values are from a Wald test of the $Z$ statistic against the null model. Significant parameters are indicated by bold font.

\begin{tabular}{lccccc}
\hline \multicolumn{1}{c}{ Parameter } & Estimate & SE & $\mathbf{9 5 \%}$ CI & Importance & $\boldsymbol{P}$ \\
\hline Intercept & -3.106 & 1.83 & $(-6.69,0.48)$ & $\cdot$ & 0.090 \\
PC1 (elevation) & $\mathbf{- 1 . 5 5 0}$ & $\mathbf{0 . 4 6}$ & $\mathbf{( - 2 . 4 5 , - \mathbf { 0 . 6 5 } )}$ & $\mathbf{0 . 9 9}$ & $<\mathbf{0 . 0 0 1}$ \\
PC2 (seasonality) & 0.191 & 0.54 & $(-0.87,1.25)$ & 0.26 & 0.724 \\
\hline
\end{tabular}


Table 5. Means \pm standard errors (ppm on a dry mass basis) of tissue elemental concentrations for the purple ( $\mathrm{P}, n=12$ ), undulate ( $\mathrm{U}, n=8)$, yellow (Y, $n=16$ ), and yellow to purple (YP, $n=8)$ floral morphs of Strepthantus polygaloides at 11 sites along the western slope of the Sierra Nevada mountains, California, USA.

\begin{tabular}{cccccc}
\hline Morph & Al & Fe & Mn & Ni & Zn \\
\hline $\mathbf{P}$ & $119 \pm 24.1$ & $287 \pm 86.4$ & $40.6 \pm 7.6$ & $7910 \pm 642$ & $136 \pm 23.3-$ \\
$\mathbf{U}$ & $224 \pm 58.2$ & $248 \pm 81.5$ & $66.7 \pm 8.2$ & $12800 \pm 3360$ & $138 \pm 26.8-$ \\
$\mathbf{Y}$ & $59.3 \pm 17.6$ & $92.2 \pm 26.2$ & $47.1 \pm 12.2$ & $7830 \pm 1140$ & $90.6 \pm 11.3-$ \\
$\mathbf{Y P}$ & $96.2 \pm 11$ & $93.9 \pm 16.2$ & $48.2 \pm 13$ & $8320 \pm 1090$ & $79.2 \pm 11.8-$ \\
& & & & $\mathbf{M g}$ & $\mathbf{P}$ \\
$\mathbf{M o r p h}$ & $\mathbf{B}$ & $\mathbf{C a}$ & $\mathbf{K}$ & $6870 \pm 1010$ & $1800 \pm 149-$ \\
$\mathbf{P}$ & $46.1 \pm 4.5$ & $5530 \pm 909$ & $17300 \pm 2400$ & $5850 \pm 970$ & $2130 \pm 239-$ \\
$\mathbf{U}$ & $35.2 \pm 4.5$ & $5580 \pm 767$ & $26100 \pm 3230$ & $4490 \pm 637$ & $2770 \pm 387-$ \\
$\mathbf{Y P}$ & $49.1 \pm 6.2$ & $4520 \pm 566$ & $16000 \pm 1230$ & $6270 \pm 1270$ & $1140 \pm 121-$ \\
\hline
\end{tabular}


Table 6. Model selection by using AICc for the tissue-soil data of 11 populations of Streptanthus polygaloides, including all four morphs ( $n=44$ plants in 11 sites). In all models, the response variable is the dry mass of the given element in foliar tissue in ppm. The predictor soil variable refers to the corresponding soil element for each tissue variable. The $k$ column refers to the number of parameters in the model and $\Delta$ refers to the $\Delta$ AICc (higher values indicate less evidence). The column $\sigma$ is the ratio of within- to between-site variance; where values are missing, site variance was zero. We did not collect data on soil B, therefore the first three models lack values for tissue $\mathrm{B}$. The minimum adequate model for each element is indicated by bold italics and darker grey; models with substantial support ( $\Delta$ AICc $\leq 2.0)$ are indicated in italics with lighter grey.

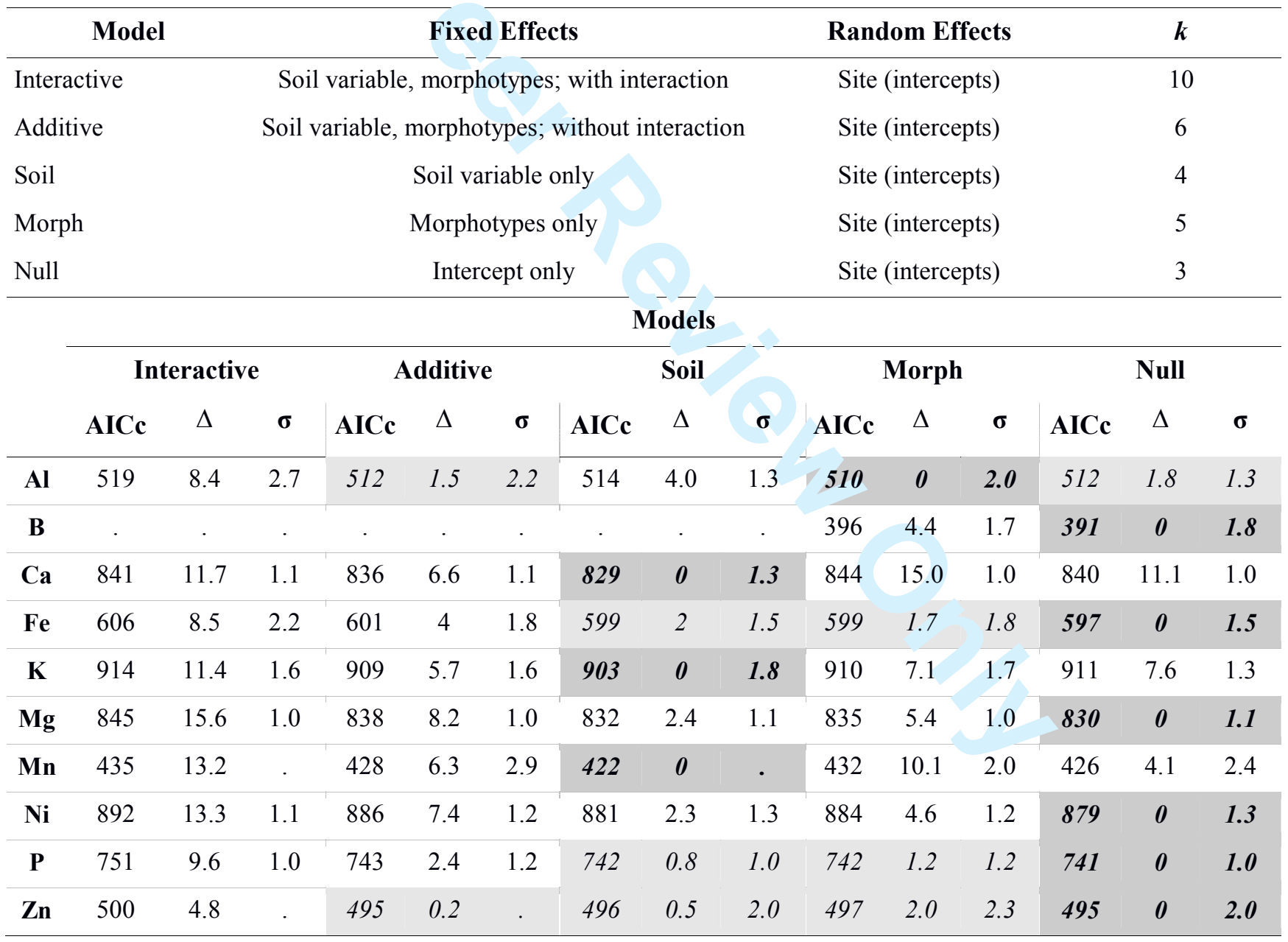


Table 7. Parameters from AICc selection of models for the Streptanthus polygaloides tissue and soil data with $\triangle \mathrm{AICc} \leq 2$ ( $n=44$ plants in 11 sites). Only mean differences and slopes that were significant at $\alpha=0.1$ are shown. Mean differences between morphs are denoted as $\mu_{\text {morph }}$ and morphindependent slopes are denoted as $b_{\text {element. Importance refers to the relative importance of variables }}$ across the model set (Burnham and Anderson 2002). Uncorrected $P$ values and FDR-corrected $q$ values are from model likelihood ratio tests between the null model and the minimum adequate (or if the null, the second to minimum adequate) model. The confidence intervals and $P$ values for mean differences among morphs are from a post-hoc Tukey test.

\begin{tabular}{|c|c|c|c|c|c|c|c|c|c|c|}
\hline Parameter & Estimate & SE & $\begin{array}{c}95 \% \\
\text { Confidence } \\
\text { Interval }\end{array}$ & & Importa & & $\chi^{2}$ & $\begin{array}{l}\text { Df } \\
(\chi)\end{array}$ & $P$ & $q$ \\
\hline & & & & $\begin{array}{c}\text { Soil } \\
\left(b_{\text {soil }}\right)\end{array}$ & $\begin{array}{c}\text { Morph } \\
\left(\mu_{\text {morph }}\right)\end{array}$ & $\begin{array}{c}\text { Soil: } \\
\text { Morph }\end{array}$ & & & & \\
\hline Al & . & . & . & 0.30 & 0.73 & 0.01 & 9.5 & 3 & 0.022 & 0.05 \\
\hline$\mu_{\mathrm{p}}-\mu_{\mathrm{u}}$ & 104 & 44 & $(1,208)$ & & . & . & . & . & 0.048 & \\
\hline$\mu_{\mathrm{u}}-\mu_{\mathrm{y}}$ & -164 & 41 & $(-265,-64)$ & & & . & . & . & $<0.001$ & \\
\hline$\mu_{\mathrm{u}}-\mu_{\mathrm{yp}}$ & -127 & 46 & $(-240,-14)$ & $\cdot$ & & . & . & . & 0.021 & \\
\hline B & . & . & . & . & 0.1 & . & 3.3 & 3 & 0.343 & 0.428 \\
\hline $\mathrm{Ca}$ & . & . & . & 0.99 & 0.04 & $\mathbf{0}$ & 13.6 & 1 & $<0.001$ & 0.004 \\
\hline$b_{\mathrm{Ca}}$ & 8.8 & 2.2 & $(4.6,13.1)$ & $\cdot$ & & & . & . & $<0.001$ & \\
\hline $\mathrm{Fe}$ & . & . & . & 0.25 & 0.29 & 0.01 & 5.9 & 3 & 0.116 & 0.166 \\
\hline$\mu_{\mathrm{p}}-\mu_{\mathrm{y}}$ & -194 & 81.3 & $(-403,14)$ & . & . & . & . & . & 0.078 & \\
\hline $\mathbf{K}$ & . & . & . & 0.95 & 0.08 & 0 & 10.1 & 1 & 0.002 & 0.01 \\
\hline$b_{\mathrm{K}}$ & 86.4 & 25.7 & $(36,137)$ & . & . & . & & . & 0.001 & \\
\hline Mg & . & . & . & 0.23 & 0.06 & $\mathbf{0}$ & 0 & 1 & 0.971 & 0.971 \\
\hline Mn & . & . & . & 0.88 & 0.04 & $\mathbf{0}$ & 6.5 & 1 & 0.011 & 0.036 \\
\hline$b_{\mathrm{Mn}}$ & -1.38 & 0.49 & $(-2.35,-0.42)$ & $\cdot$ & . & . & . & . & 0.005 & \\
\hline $\mathbf{N i}$ & . & . & . & 0.24 & 0.09 & $\mathbf{0}$ & 0.2 & 1 & 0.694 & 0.771 \\
\hline $\mathbf{P}$ & . & . & . & 0.38 & 0.34 & $\mathbf{0}$ & 6.5 & 3 & 0.088 & 0.147 \\
\hline$\mu_{\mathrm{y}}-\mu_{\mathrm{yp}}$ & -1632 & 574 & $(-3110,-160)$ & . & . & . & . & . & 0.023 & \\
\hline $\mathbf{Z n}$ & . & . & . & 0.53 & 0.44 & 0.03 & 10.3 & 4 & 0.035 & 0.070 \\
\hline$\mu_{\mathrm{p}}-\mu_{\mathrm{y}}$ & -51.5 & 25.3 & $(-106.5,3.2)$ & . & . & . & . & . & 0.074 & \\
\hline \multicolumn{11}{|c|}{31} \\
\hline
\end{tabular}


1

2

3

4

5

6

7

8

9

10

11

12

13

14

15

16

17

18

19

20

21

22

23

24

25

26

27

28

29

30

31

32

33

34

35

36

37

38

39

40

41

42

43

44

45

46

47

48

49

50

51

52

53

54

55

56

57

58

59

60

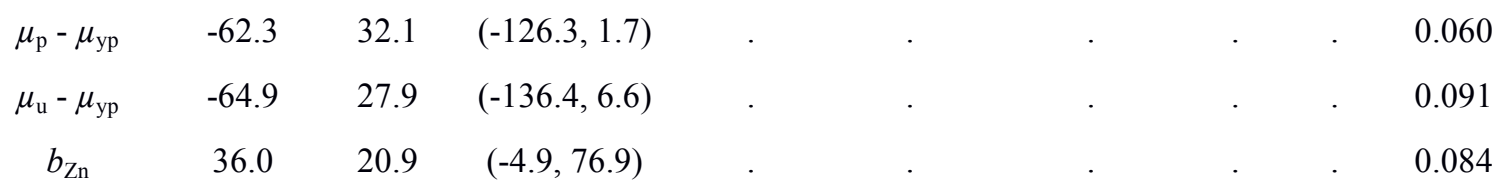

URL: http:/mc.manuscriptcentral.com/tped 
Table 8. Mean values for soil elemental concentrations for the four morphs of Streptanthus polygaloides (soil-only data), and a comparison of a model including morph as a fixed effect (and site as a random effect) versus a model with only a random site effect. $\Delta$ refers to $\Delta$ AICc, and $\sigma$ is the ratio of within- to between-site variance for the null model are given. Uncorrected $P$ values and FDRcorrected $q$ values are from a likelihood ratio test between the two models. Superscripted letters indicate groups that differed significantly $(\alpha=0.05)$ in a post-hoc Tukey test. Bold font and dark grey indicates significant $P / q$ values and the minimum adequate model, while italics and light grey indicate models with substantial support $(\triangle \mathrm{AICc} \leq 2)$.

\begin{tabular}{|c|c|c|c|c|c|c|c|c|c|c|c|}
\hline & \multicolumn{4}{|c|}{ Morph means } & \multicolumn{4}{|c|}{ Model } & \multirow{3}{*}{$\boldsymbol{\sigma}$} & \multirow{3}{*}{$P$} & \multirow{3}{*}{$q$} \\
\hline & $\mathbf{P}$ & $\mathbf{U}$ & $\mathbf{Y}$ & $\mathbf{Y P}$ & \multicolumn{2}{|c|}{ Morph } & \multicolumn{2}{|c|}{ Null } & & & \\
\hline & & & & & AICc & $\Delta$ & AICc & $\Delta$ & & & \\
\hline Al & $4.31 \pm 1.94$ & $0.78 \pm 0.11$ & $2.01 \pm 0.36$ & $1.66 \pm 0.5$ & 106.7 & 3.2 & 103.5 & 0 & 0.9 & 0.219 & 0.398 \\
\hline $\mathbf{C a}$ & $332 \pm 54^{\mathrm{A}}$ & $424 \pm 36^{\mathbf{A}, \mathbf{B}}$ & $273 \pm 29^{\mathbf{A}}$ & $548 \pm 100^{\mathbf{B}}$ & 589.3 & 0 & 591.3 & 2.0 & 1.4 & 0.022 & 0.110 \\
\hline Cd & $0.07 \pm 0.009$ & $0.032 \pm 0.002$ & $0.072 \pm 0.008$ & $0.051 \pm 0.011$ & -185.1 & 1.7 & -183.5 & 0 & 1.0 & 0.111 & 0.317 \\
\hline $\mathrm{Cr}$ & $0.19 \pm 0.02$ & $0.20 \pm 0.01$ & $0.17 \pm 0.01$ & $0.19 \pm 0.01$ & 12.7 & 4.3 & 8.4 & 0 & 2.5 & 0.341 & 0.568 \\
\hline $\mathbf{C u}$ & $1.73 \pm 0.42$ & $1.54 \pm 0.12$ & $1.03 \pm 0.14$ & $0.76 \pm 0.11$ & 64.0 & 3.0 & 61.0 & 0 & 0.7 & 0.198 & 0.396 \\
\hline $\mathbf{F e}$ & $33.1 \pm 3.7^{\mathbf{A}}$ & $16.2 \pm 1.6^{\mathbf{B}}$ & $28.4 \pm 2.2^{\mathrm{A}, \mathbf{C}}$ & $22.4 \pm 3.1^{\mathrm{B}, \mathrm{C}}$ & 333.8 & 0 & 339.2 & 5.4 & 1.7 & 0.004 & 0.040 \\
\hline $\mathbf{K}$ & $31.3 \pm 5^{\mathrm{A}}$ & $123 \pm 14.1^{\mathbf{B}}$ & $43.8 \pm 8.4^{\mathbf{A}}$ & $48.6 \pm 10.6^{\mathbf{A}}$ & 434.2 & 0 & 442.0 & 7.8 & 0.7 & 0.001 & 0.020 \\
\hline Mg & $1160 \pm 170$ & $1740 \pm 310$ & $1200 \pm 160$ & $1360 \pm 130$ & 687.7 & 5.5 & 693.2 & 0 & 1.0 & 0.530 & 0.707 \\
\hline Mn & $13.3 \pm 2.5$ & $8.6 \pm 1.3$ & $17.6 \pm 3.2$ & $12.1 \pm 3.8$ & 92.8 & 6.3 & 86.5 & 0 & 0.8 & 0.709 & 0.886 \\
\hline Mo & $0.06 \pm 0.01^{\mathbf{A}}$ & $0.10 \pm 0.01^{\mathbf{B}}$ & $0.06 \pm 0.01^{\mathrm{A}}$ & $0.07 \pm 0.01^{\mathbf{A}, \mathbf{B}}$ & -209.6 & 0 & -209.0 & 0.6 & 0.8 & 0.041 & 0.137 \\
\hline $\mathbf{N a}$ & $3.26 \pm 1.13^{\mathbf{A}}$ & $7.39 \pm 0.55^{\mathbf{B}}$ & $8.32 \pm 0.57^{\mathbf{B}}$ & $5.01 \pm 0.36^{\mathbf{A}, \mathbf{B}}$ & 11.8 & 0 & 15.5 & 3.7 & 0.2 & 0.009 & 0.060 \\
\hline $\mathbf{N H}_{4}$ & $2.15 \pm 0.52$ & $2.75 \pm 0.45$ & $2.48 \pm 0.40$ & $2.7 \pm 0.55$ & 83.8 & 6.8 & 77.0 & 0 & 0.9 & 0.829 & 0.975 \\
\hline $\mathbf{N i}$ & $50.8 \pm 10.3$ & $15.8 \pm 2.0$ & $48 \pm 6.6$ & $26.3 \pm 5.4$ & 415.2 & 2.2 & 413.0 & 0 & 1.0 & 0.140 & 0.344 \\
\hline $\mathrm{NO}_{3}$ & $4.13 \pm 1.4$ & $3.21 \pm 0.71$ & $2.59 \pm 0.64$ & $3.26 \pm 1.12$ & 119.5 & 7.3 & 112.2 & 0 & 0.8 & 0.945 & 0.978 \\
\hline $\mathbf{P}$ & $0.93 \pm 0.07$ & $1.5 \pm 0.32$ & $1.02 \pm 0.08$ & $0.98 \pm 0.07$ & 27.0 & 4.9 & 22.1 & 0 & 0.9 & 0.422 & 0.649 \\
\hline $\mathbf{P b}$ & $1.47 \pm 0.38$ & $0.52 \pm 0.06$ & $15.45 \pm 10.12$ & $0.91 \pm 0.23$ & 145.2 & 2.4 & 142.8 & 0 & 1.4 & 0.155 & 0.344 \\
\hline $\mathbf{S}$ & $2.91 \pm 0.25$ & $3.23 \pm 0.2$ & $3.02 \pm 0.15$ & $3.17 \pm 0.47$ & 7.0 & 7.2 & -0.2 & 0 & 0.9 & 0.925 & 0.978 \\
\hline $\mathbf{Z n}$ & $0.85 \pm 0.15$ & $0.65 \pm 0.09$ & $1.01 \pm 0.11$ & $0.8 \pm 0.19$ & 72.7 & 5.3 & 67.4 & 0 & 1.3 & 0.500 & 0.707 \\
\hline pH & $6.81 \pm 0.08^{\mathbf{A}}$ & $7.31 \pm 0.09^{\mathbf{B}}$ & $6.87 \pm 0.07^{\mathbf{A}}$ & $7.12 \pm 0.1^{\mathbf{A}, \mathbf{B}}$ & 15.5 & 0 & 16.4 & 1.0 & 0.9 & 0.035 & 0.137 \\
\hline
\end{tabular}


1

2

3

4

5

6

7

8

9

10

11

12

13

14

15

16

17

18

19

20

21

22

23

24

25

26

27

28

29

30

31

32

33

34

35

36

37

38

39

40

41

42

43

44

45

46

47

48

49

50

51

52

53

54

55

56

57

58

59

60

\begin{tabular}{llllllllllll} 
LOI & $2.48 \pm 0.55$ & $1.99 \pm 0.14$ & $2.31 \pm 0.31$ & $2.5 \pm 0.71$ & 89.0 & 7.5 & $\mathbf{8 1 . 5}$ & $\mathbf{0}$ & 1.0 & 0.978 & 0.978 \\
\hline
\end{tabular} 


\section{Figure captions.}

Figure 1. Map of Streptanthus polygaloides collections used in the analyses of morph occurrence and tissue-soil chemistry. Arrows indicate those populations from which tissue and soil samples were analysed for elemental composition. Some highly overlapping points within morphotypes have been removed for clarity. Only two contour lines are shown, at 500 and $1500 \mathrm{~m}$.

Figure 2. Model-averaged conditional predicted probabilities for yellow versus purple calyx coloration along an climatic gradient in the Sierra Nevada, California, USA, from herbarium collections of Streptanthus polygaloides $(n=99)$. Dotted lines represent a 95\% confidence interval around the predictions.

Figure 3. Scatter plots showing correlations between soil and tissue concentrations (ppt dry mass) for $\mathrm{Ca}, \mathrm{K}$, and $\mathrm{Mn}$, and bar plots showing foliar concentrations of $\mathrm{P}$ and $\mathrm{Al}$ among morphs. Letters in bar plots indicate morphs that differed significantly. Regression slopes and mean differences are from Table 8; only those that were significant at $\alpha=0.05$ are shown.

Supplemental Figure S1. Variance components from all models in Table 6. The proportional variances of estimated random effects are shown as stacked bars, and the $F$-values of the fixed effects (the numerator of the $F$-ratio) are shown as lines. 


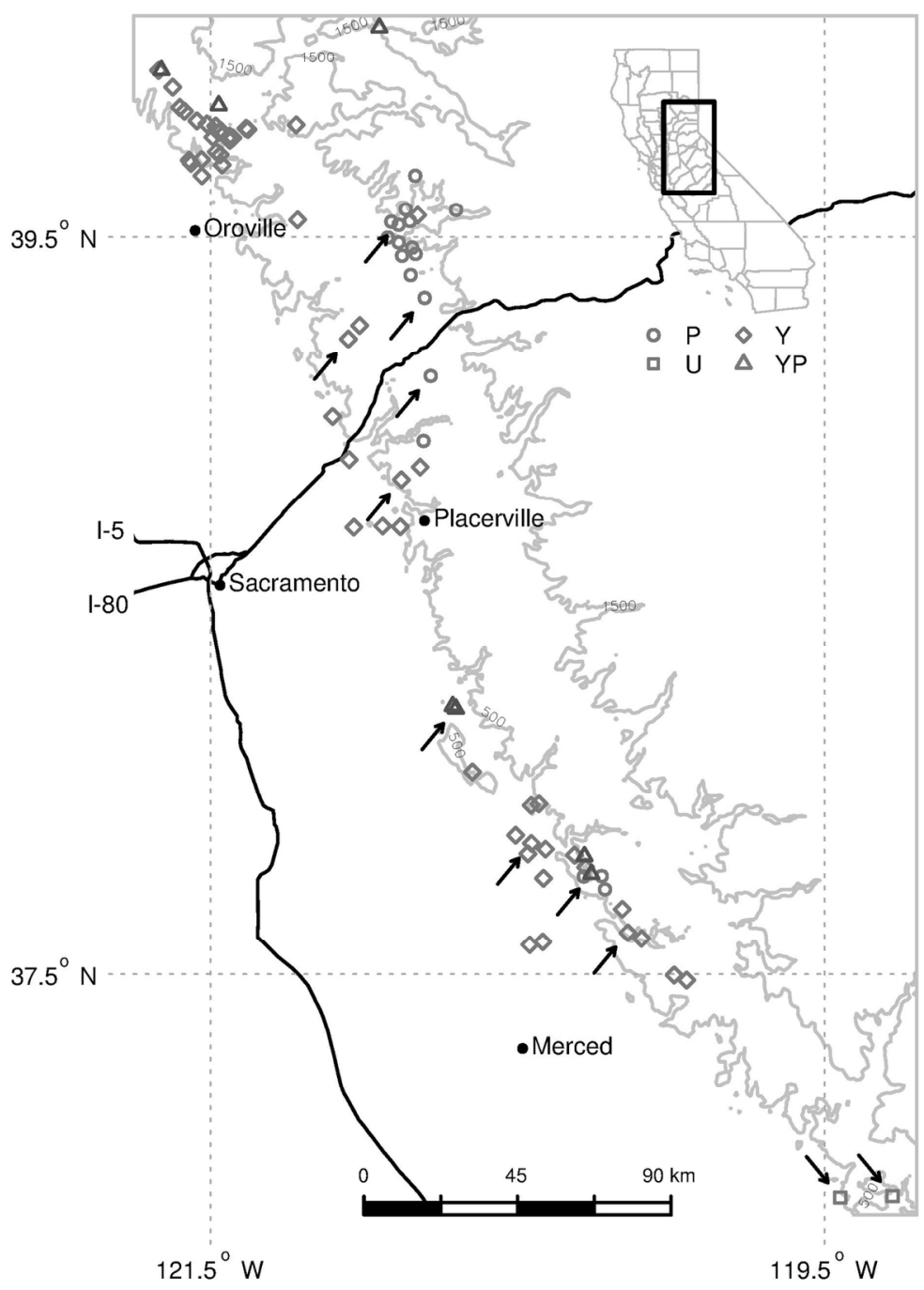

$127 \times 181 \mathrm{~mm}(300 \times 300 \mathrm{DPI})$

URL: http:/mc.manuscriptcentral.com/tped 


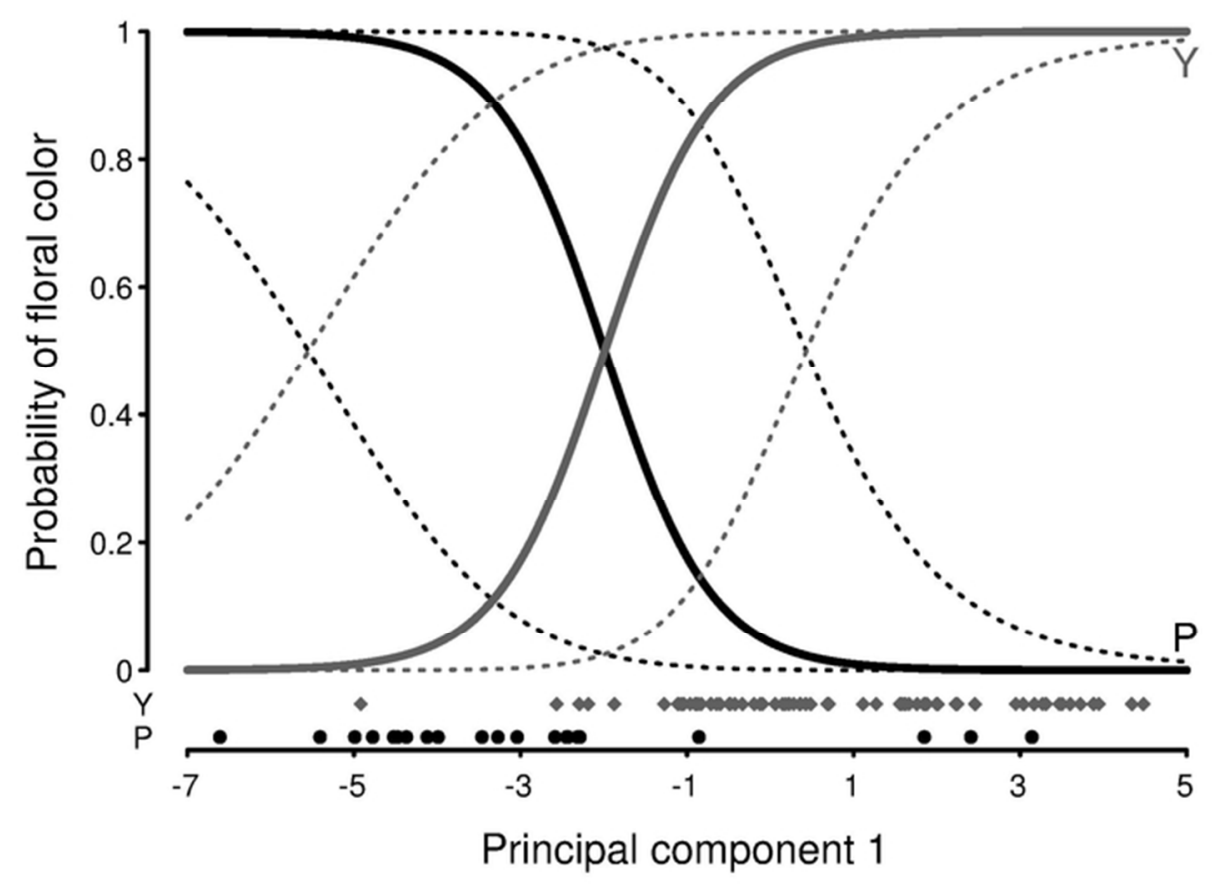

$63 \times 45 \mathrm{~mm}(300 \times 300 \mathrm{DPI})$ 

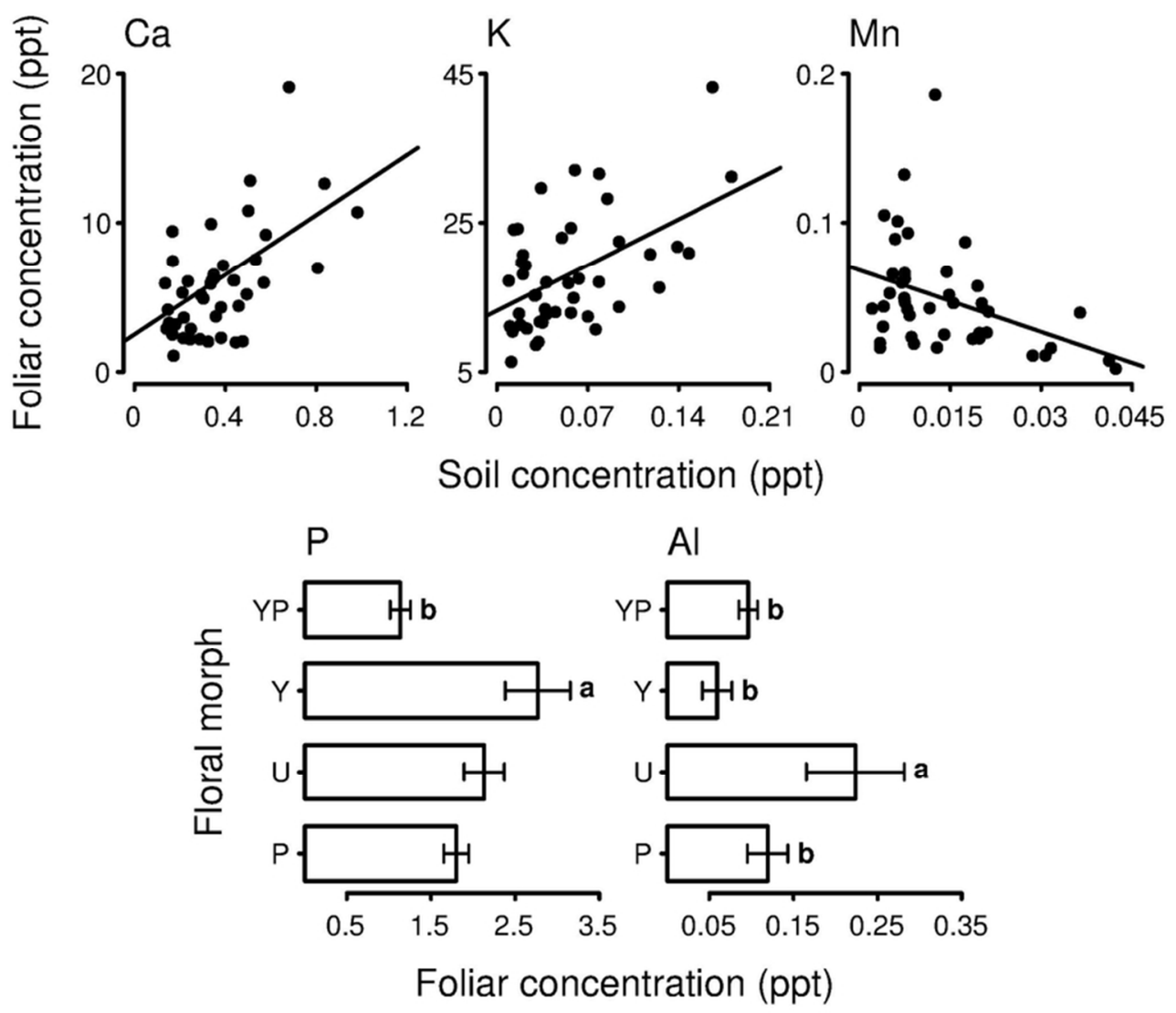

$76 \times 65 \mathrm{~mm}(300 \times 300$ DPI) 


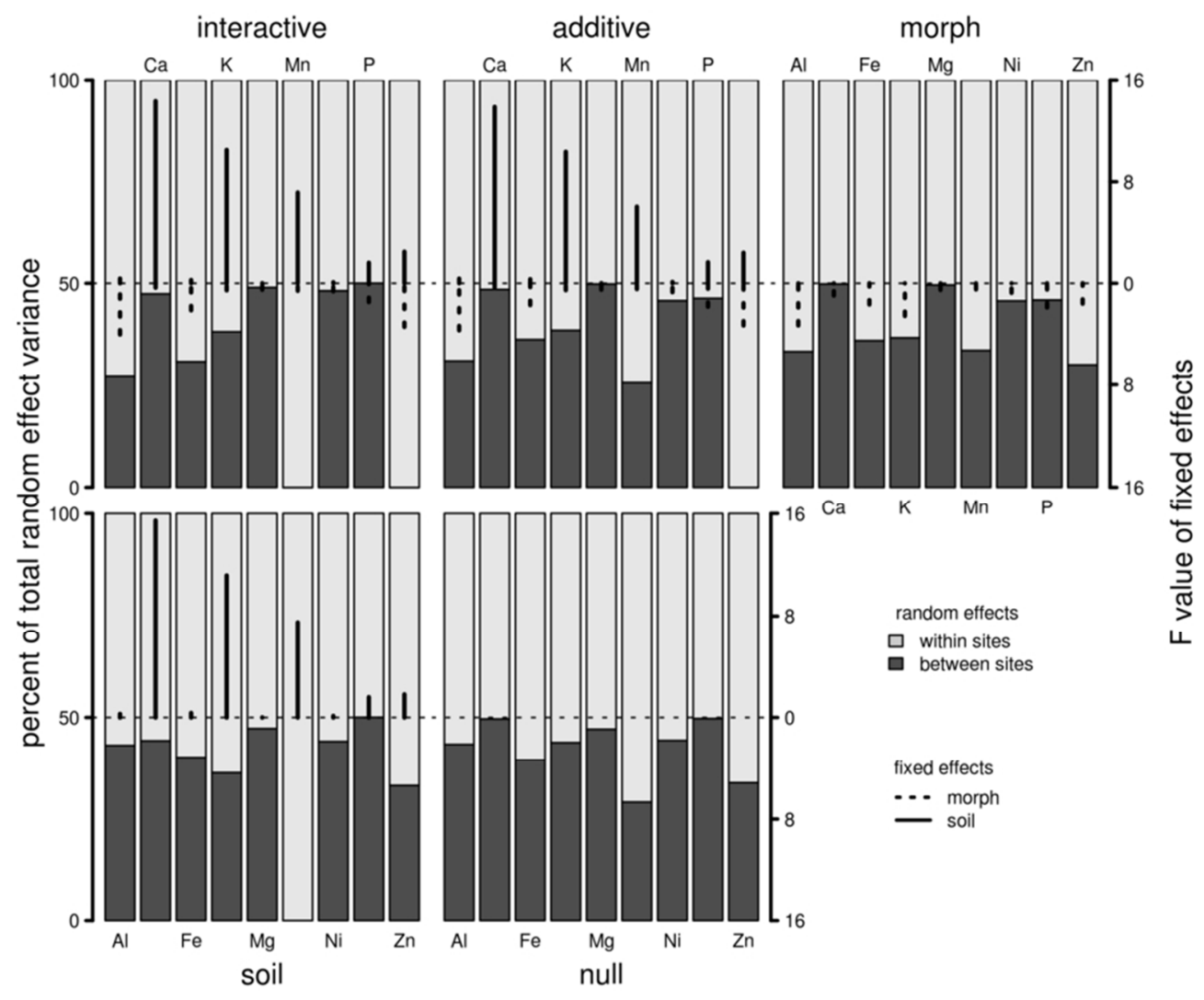

$76 \times 65 \mathrm{~mm}(300 \times 300$ DPI $)$ 